\title{
CMR
}

\section{Isolation and characterization of the Chrysanthemum nitrate transporter CmNRT1}

\author{
C.S. Gu, X.X. Zhang, S.M. Chen, T. Li, Y. Chen, J.F. Jiang and F.D. Chen
}

College of Horticulture, Nanjing Agricultural University, Nanjing, China

Corresponding author: F.D. Chen

E-mail: chenfd@njau.edu.cn

Genet. Mol. Res. 15 (1): gmr.15017148

Received August 6, 2015

Accepted October 19, 2015

Published January 26, 2016

DOI http://dx.doi.org/10.4238/gmr.15017148

ABSTRACT. In this study, the nitrate transporter gene CmNRT1 was isolated from the chrysanthemum variety 'Nannongxuefeng'. The full-length cDNA contains an open reading frame of 1761 bp encoding 587 residues. Using qRT-PCR, we found that $\mathrm{CmNRT1}$ was induced by $10 \mathrm{mM} \mathrm{NO}_{3}^{-}$in roots and shoots. Two Arabidopsis thaliana transgenic plants expressing CmNRT1 were selected for functional analyses. Root ${ }^{15} \mathrm{~N}$ influx in wild-type and transgenic $A$. thaliana lines under 10 or $0.2 \mathrm{mM}^{15} \mathrm{NO}_{3}$ was tested. Our results indicate that $\mathrm{CmNRT1}$ encodes a constitutive component for a lowaffinity transporter.

Key words: Chrysanthemum; Nitrogen; Nitrate transporter 


\section{INTRODUCTION}

Nitrogen, an essential macronutrient for plants (Covelo et al., 2008; Zhang et al., 2008), is a constituent of numerous important compounds including amino acids, proteins (enzymes), nucleic acids, chlorophyll, and several plant hormones (Britto and Kronzucker, 2004; Guo et al., 2008). Because of the important influence of nitrogen on plant growth, a number of studies have examined the basis of nitrogen use efficiency in cotton (Li et al., 2007), rice (Koutroubas and Ntanos, 2003) and maize (Presterl et al., 2002). Three nitrate transporter gene families NRT1s, $N R T 2 s$, and NAR2s have been identified that code for a high-affinity nitrate transport system and low-affinity nitrate transport system (Kotur et al., 2012). The first plant nitrate transporter discovered, CHL1, was identified in Arabidopsis (Tsay et al., 1993) and was shown to be a dual-affinity nitrate transporter involved in multiple phases of nitrate uptake (Liu et al., 1999). The functions of AtNRT1 gene family members have since been gradually established. AtNRT1.5 is responsible for xylem loading of nitrate (Lin et al., 2008); AtNRT1.6 has a role in early embryo development (Almagro et al., 2008); AtNRT1.7 is responsible for source-to-sink remobilization of nitrates (Fan et al., 2009); AtNRT1.8 functions in nitrate removal from the xylem sap and mediates cadmium tolerance (Li et al., 2010); AtNRT1.9 is important in phloem nitrate transport (Wang and Tsay, 2011), and AtNRT1.11 and AtNRT1.12 play a key role in redistributing xylem-borne nitrates to enhance plant growth (Hsu and Tsay, 2013). NRT1 genes have also been identified in Brassica napus (Zhou et al., 1998; Faure-Rabasse et al., 2002), rice (Lin et al., 2000; Ma et al., 2011), and Chinese cabbage (Yang et al., 2012).

Chrysanthemums (Chrysanthemum morifolium) are one of the world's four most popular species for cut flowers. Owing to their high commercial value, large amounts of nitrogen fertilizer are applied to chrysanthemum cultivation to induce high flower production. However, a significant proportion of the applied nitrogen fertilizer is lost to the atmosphere or ground water due to the low nitrogen use efficiency of commercial chrysanthemum cultivars. This loss not only causes serious pollution to the environment but also adversely affects the yield and quality of cut chrysanthemum (Barbosa et al., 2000). The selection of chrysanthemum varieties that have high nitrogen acquisition and the identification of genes that code for nitrogen uptake transporters will therefore be important for improving chrysanthemum cultivation. In this study, we screened for chrysanthemum genotypes for high nitrogen acquisition. This screen identified a candidate nitrogen uptake transporter, CmNRT1, that was inducible by nitrates. Analysis of transgenic Arabidopsis thaliana suggested that $C m N R T 1$ encodes a constitutive component for a low-affinity transporter.

\section{MATERIAL AND METHODS}

\section{Plant materials and growing conditions}

The chrysanthemum varieties 'Nannongxuefeng', 'Nannongyuzhu', 'Nannongxiaoli', 'Nannonggongfen', 'Nannongxiaguang', 'Nannonghualian', 'Nannongshuangjiao', 'Nannongyudie', 'Nannongxunzhang', 'Nannongzixunzhang', 'Nannonghongxiu', 'Nannonghongfen', 'Nannongyupan', 'Nannongchifeng', 'Nannongyinshan', and 'Nannongjindie' were obtained from the Chrysanthemum Germplasm Resource Preserving Centre, Nanjing Agricultural University, China. Cuttings were induced to form roots by immersion in 1/4 strength Murashige and Skoog medium for 2 weeks. Phenotypically uniform seedlings at the 8-leaf stage were transferred to a 8-L nutrient 
solution (5 mM NH $\mathrm{NO}_{3}, 2.5 \mathrm{mM} \mathrm{K}_{2} \mathrm{SO}_{4}, 1.5 \mathrm{mM} \mathrm{MgSO}_{4} .7 \mathrm{H}_{2} \mathrm{O}, 1.33 \mathrm{mM} \mathrm{NaH}_{2} \mathrm{PO}_{4} .2 \mathrm{H}_{2} \mathrm{O}, 2.0 \mathrm{mM}$ $\mathrm{CaCl}_{2}, 20 \mu \mathrm{M} \mathrm{H}_{3} \mathrm{BO}_{3}, 9 \mu \mathrm{M} \mathrm{MnCl}_{2} \cdot 4 \mathrm{H}_{2} \mathrm{O}, 0.77 \mu \mathrm{M} \mathrm{ZnSO}_{4} \cdot 7 \mathrm{H}_{2} \mathrm{O}, 0.32 \mu \mathrm{M} \mathrm{CuSO}_{4} \cdot 5 \mathrm{H}_{2} \mathrm{O}, 0.39 \mu \mathrm{M}$ $\mathrm{Na}_{2} \mathrm{MoO}_{4} \cdot 2 \mathrm{H}_{2} \mathrm{O}, 20 \mu \mathrm{M}$ FeNaEDTA, pH 6.5). To inhibit nitrification, $7 \mu \mathrm{M}$ dicyandiamide was added to the solution. Two groups of five plants were treated with a low level of nitrogen $\left(0.2 \mathrm{mM} \mathrm{NH}_{4} \mathrm{NO}_{3}\right)$ or a normal nitrogen level $\left(4 \mathrm{mM} \mathrm{NH}_{4} \mathrm{NO}_{3}\right)$. The concentrations were selected based on previous reports on chrysanthemums (Jiang et al., 2008; Huang et al., 2010). The relative nitrogen content in chrysanthemums exposed to low nitrogen content compared to normal nitrogen content was used to estimate nitrogen uptake efficiency. Sixteen chrysanthemum varieties were grown for 21 days in sand culture to select those with the lowest and high nitrogen uptake. In the sand culture, the size of the quartz grains ranged from 0.45 to $1 \mathrm{~mm}$. The quartz grains were first washed with distilled water, then with $2 \mathrm{M} \mathrm{HCl}$ for $24 \mathrm{~h}$, washed again in distilled water, and sterilized at $170^{\circ} \mathrm{C}$ for $2 \mathrm{~h}$ in an oven (Liao et al., 2003). Each pot contained one plant.

\section{Determination of nitrogen content}

At harvest, the seedlings were washed thoroughly with distilled water. To determine nitrogen contents, the plants were washed with $0.1 \mathrm{mM} \mathrm{CaSO}_{4}$ for $1 \mathrm{~min}$, then placed at $105^{\circ} \mathrm{C}$ for $30 \mathrm{~min}$ to inactivate enzymes, and finally dried at $80^{\circ} \mathrm{C}$. The dry weight was recorded. The concentration of nitrogen in the plants was determined by the Kjeldahl method (Shi et al., 2010). The experimental samples were digested with $\mathrm{H}_{2} \mathrm{SO}_{4}-\mathrm{H}_{2} \mathrm{O}_{2}$, subjected to a distillation process, and then nitrogen levels were determined.

\section{Isolation and sequencing of CmNRT1 full-length cDNA}

For gene cloning, chrysanthemum seedlings were grown in IRRI solution containing $4 \mathrm{mM}$ $\mathrm{NH}_{4} \mathrm{NO}_{3}$ for 4 weeks and then starved of nitrogen for 1 week. Total RNA was isolated from the root of nitrogen-starved seedlings given $5 \mathrm{mM} \mathrm{NO}_{3}^{-}$(supplied as $\mathrm{KNO}_{3}$ ). Total RNA was extracted using the RNAiso reagent (TaKaRa) following the manufacturer instructions and treated with RNase-free DNasel (TaKaRa). The concentration and the integrity of the RNA were assessed as described by $\mathrm{Gu}$ et al. (2011). The first cDNA strand was synthesized using Reverse Transcriptase M-MLV $\left(\mathrm{RNase} \mathrm{H}^{-}\right.$) (TaKaRa) according to the manufacturer instructions. A partial CmNRT1 sequence was selected from chrysanthemum-expressed sequence tags (Chen et al., 2009). The remainder of the sequence was acquired using RACE-PCR as described by Gu et al. (2014a). The open reading frame (ORF) within the amplicons was identified using the ORF finder software (www.ncbi.nlm.nih. gov), and its deduced peptide sequence was subjected to a BLASTp search to identify homologs. The phylogeny of the sequences was derived using the DNAman software package.

\section{Real-time RT-PCR}

Cuttings were grown in nutrient solution as above for 4 weeks and then starved of nitrogen for 1 week. Total RNA was isolated from the root tissue of plants supplied with either 0.5 or 10 $\mathrm{mM} \mathrm{KNO}_{3}$ and sampled at $0,0.5,1,2,4,6,8$, or $12 \mathrm{~h}$. The transcription profiles of CmNRT1 were obtained by real-time RT-PCR based on SYBR ${ }^{\circledR}$ Premix Ex Taq ${ }^{\mathrm{TM}}$ II (Perfect Real-Time) (TaKaRa). The PCR comprised an initial denaturation step of $95^{\circ} \mathrm{C}$ for $60 \mathrm{~s}$, followed by 40 cycles of $95^{\circ} \mathrm{C}$ for $15 \mathrm{~s}, 55^{\circ} \mathrm{C}$ for $30 \mathrm{~s}$ and $72^{\circ} \mathrm{C}$ for $30 \mathrm{~s}$. At the end of the $\mathrm{PCR}$, the temperature was raised from 
$55^{\circ}$ to $95^{\circ} \mathrm{C}$ at a rate of $0.5^{\circ} \mathrm{C} / \mathrm{s}$ to generate the required denaturation curve. CmpsaA (AB548817) was used as the reference gene (Gu et al., 2011). Primer sequences are listed in Table 1. Each PCR was repeated as three biological replicates, and the relative changes in transcription were analyzed using the $2^{-\Delta \Delta \mathrm{Ct}}$ approach (Livak and Schmittgen, 2001).

\begin{tabular}{|c|c|c|}
\hline Primer & Sequence $\left(5^{\prime}-3^{\prime}\right)$ & Usage \\
\hline Oligo (dT) primer & GACTCGAGTCGACATCGATTTTTTTTTTTTTTTTT & 3'-RACE \\
\hline CmNRT1GSP1 & TGAATCACAGGTGGCAAAA & \\
\hline CmNRT1GSP2 & GGTAACGCTAACGCTGCTA & \\
\hline dT-AP & GACTCGAGTCGACATCGA & \\
\hline CmNRT1AGSP1 & TTCCTCCACGCCCCGATA & 5'-RACE \\
\hline CmNRT1AGSP2 & CAGCGTCTCCCAAGGTTG & \\
\hline CmNRT1AGSP3 & CCTCCTGTTCCGAGTGCG & \\
\hline AAP & GGCCACGCGTCGACTAGTACGGG\|GGGIIGGGIIG & \\
\hline AUAP & GGCCACGCGTCGACTAGTAC & \\
\hline CmNRT1SP & TCTCCTTACTCTACATTTATTT & ORF amplification \\
\hline CmNRT1AP & AACCTAACAAAATAACGG & \\
\hline CmNRT1-P1 & TCAGCAACAAAACCACCG & Promoter cloning \\
\hline CmNRT1-P2 & AGCCTTTCACATGCCTCC & \\
\hline CmNRT1-P3 & GCTTGTCCAGCCGCCAGT & \\
\hline CmNRT1-R1 & CGGAGCTTCACTTGTCGG & \\
\hline CmNRT1-R2 & TGGGGCGTTTCTGGGTCT & \\
\hline CmNRT1-R3 & CCGTGCGTTGCTCTGCTT & \\
\hline qCmNRT1 & ATGACGAAGAAATGACGGAG & qRT-PCR \\
\hline qACmNRT1 & AGAGGCTGCCATCAATACCC & \\
\hline psaA-F & CCAATAACCACGACCGCTAA & \\
\hline psaA-R & GGCACAGTCCTCCCAAGTAA & \\
\hline
\end{tabular}

RACE $=$ rapid-amplification of CDNA ends.

\section{Transgene construction and $A$. thaliana transformation}

The CmNRT1 ORF was amplified using the primer pair CmNRTF/R (Table 1) and inserted into the BamHI and Sall sites of pCAMBIA1301-220 following digestion with these two enzymes. The construct was named pCAMBIA1301-220-CmNRT1. This construct was transformed into $A$. tumefaciens strain EHA105 using the freeze-thaw method (Liu et al., 2012). A. thaliana Col-0 (ecotype Columbia) was transformed via the floral dip method (Liu et al., 2012). $T_{1}$ seedlings were raised on agar containing $20 \mathrm{mg} / \mathrm{L}$ hygromycin and $25 \mathrm{mg} / \mathrm{L}$ ampicillin. Positive transformants were confirmed by histochemical evaluation of GUS expression in leaves (Remans et al., 2006), and by PCR using genomic DNA and the primer pair CmNRTF/R (Table 1). The qRT-PCR validation was based on Arabidopsis cDNA amplified by the primers CmNRTs/x (Table 1). The primers for the reference gene AtUBQ (NM_116771.5) were AtUBQs/x (Table 1).

\section{Root ${ }^{15} \mathrm{~N}$ influx}

The influx of ${ }^{15} \mathrm{NO}_{3}-$ into seedlings of transgenic and non-transgenic lines was assayed as described previously (Ho et al., 2009). Briefly, 10-day-old wild-type and two CmNRT1 transgenic lines were first exposed to $\mathrm{pH} 6.5$ nitrate-free growth medium and then to $\mathrm{pH} 5.5$ nitrate-free 
medium for $3 \mathrm{~h}$. The plants were washed and transferred to $\mathrm{pH} 5.5$ nitrate medium containing 10 or $0.2 \mathrm{mM}^{15} \mathrm{NO}_{3}$ for 30 min and finally to $0.1 \mathrm{mM} \mathrm{CaSO}_{4}$ for $1 \mathrm{~min}$. The influx of ${ }^{15} \mathrm{~N}$ was determined and calculated as described by Gu et al. (2014b). Dried root tissue was analyzed using the ANCAMS system (PDZ Europa).

\section{RESULTS}

\section{Screening chrysanthemum genotypes for nitrogen acquisition abilities}

As shown in Table 2, the relative nitrogen contents of 'Nannongxiaoli', 'Nannongxuefeng', and 'Nannongyuzhu' were $0.757,0.840$, and 0.788 , while those in 'Nannonghualian', 'Nannonggongfen', and 'Nannongxiaguang' were $0.645,0.568$, and 0.616 , respectively. The lowest and highest relative nitrogen contents were in 'Nannonggongfen' and 'Nannongxuefeng', respectively.

\section{Table 2. Relative nitrogen content of 16 cut chrysanthemum cultivars.}

\begin{tabular}{l|l}
\hline Cultivar & Relative nitrogen content $^{\star}$ \\
\hline Nannongxuefeng & $0.840 \pm 0.060^{\mathrm{a}}$ \\
\hline Nannongyuzhu & $0.788 \pm 0.025^{\mathrm{b}}$ \\
\hline Nannongxiaoli & $0.757 \pm 0.026^{\mathrm{bc}}$ \\
\hline Nannonggongfen & $0.568 \pm 0.017^{\mathrm{i}}$ \\
\hline Nannongxiaguang & $0.616 \pm 0.023^{\mathrm{h}}$ \\
\hline Nannonghualian & $0.645 \pm 0.013^{\mathrm{h}}$ \\
\hline Nannongshuangjiao & $0.689 \pm 0.012^{\mathrm{g}}$ \\
\hline Nannongyudie & $0.692 \pm 0.014^{\mathrm{fg}}$ \\
\hline Nannongxunzhang & $0.752 \pm 0.018^{\mathrm{bc}}$ \\
\hline Nannongzixunzhang & $0.723 \pm 0.012^{\mathrm{def}}$ \\
\hline Nannonghongxiu & $0.712 \pm 0.016^{\mathrm{efg}}$ \\
\hline Nannonghongfeng & $0.762 \pm 0.016^{\mathrm{bc}}$ \\
\hline Nannongyupan & $0.759 \pm 0.020^{\mathrm{bc}}$ \\
\hline Nannongchifeng & $0.759 \pm 0.020^{\mathrm{cd}}$ \\
\hline Nannongjindie & $0.758 \pm 0.020^{\mathrm{cd}}$ \\
\hline
\end{tabular}

*Results with the same letter are not significantly different.

\section{CmNRT1 and its predicted product}

The CmNRT1 gene was isolated by RT-PCR and RACE methods using information from chrysanthemum EST libraries (Figure 1A). The full-length CmNRT1 cDNA consisted of a 1761-bp ORF encoding 587 amino acids. The predicted gene product is a protein of molecular mass 64.90 $\mathrm{kDa}$ and $\mathrm{a}$ pl of 9.14. Its amino acid sequence shared high similarity with AtNRT1.1, BdNRT1.1, BnNRT1.2, CsNRT1.1, GmNRT1.1, NpNRT1.1, PpNRT1, and VvNRT1.1 (Figure 1B). GmNRT1.1 and CmNRT1 proteins were closest in the phylogenetic tree (Figure 1C). 
A
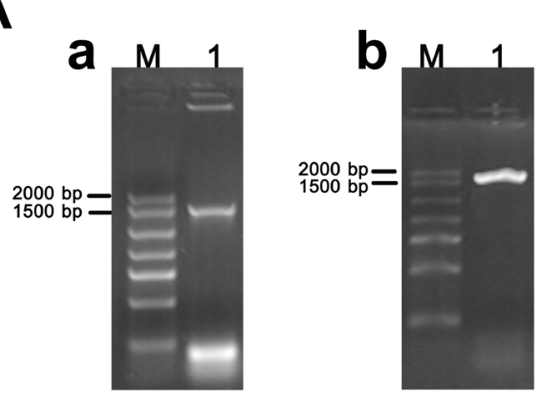

C

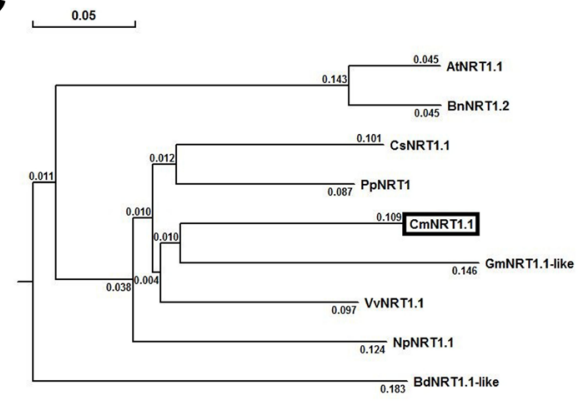

B
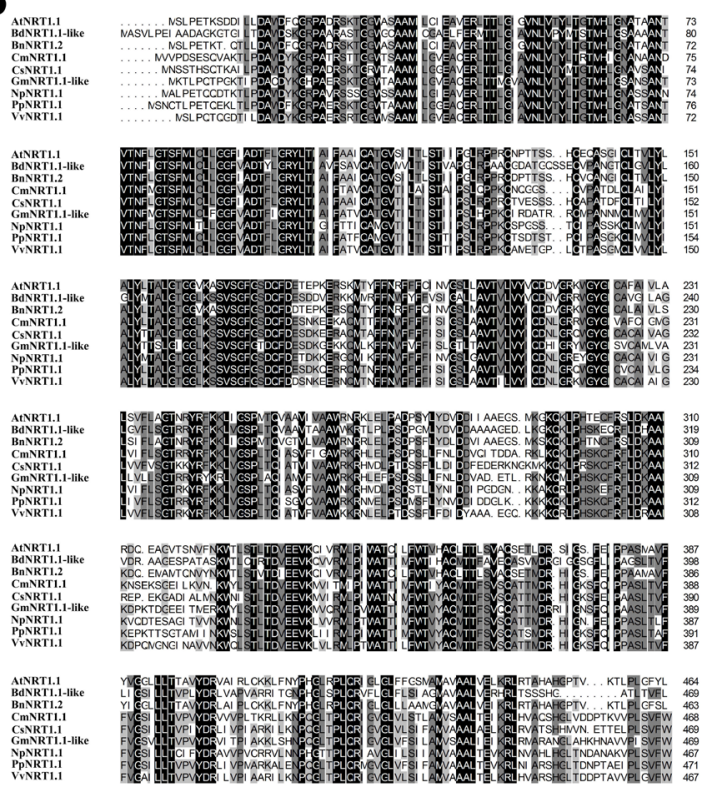

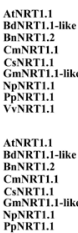

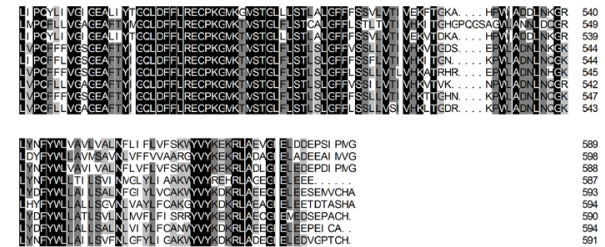

Figure 1. Cloning and analysis of CmNRT1. A. PCR amplification of CmNRT1.1: (a) 3'-RACE of CmNRT1; (b) Fulllength cDNA of CmNRT1. B. Alignment of the derived amino acid sequences from CmNRT1 with other NRT1s. The source and accession numbers of the amino acids are as follows: AtNRT1.1 (Arabidopsis thaliana NP_563899), BdNRT1.1-like (Brachypodium distachyon XP_003574312), BnNRT1.2 (Brassica napus AAA80582), CsNRT1.1 (Cucumis sativus ADQ74763), GmNRT1.1-like (Glycine max XP_003549905), NpNRT1.1 (Nicotiana plumbaginifolia CAC00544), PpNRT1 (Prunus persica BAD22820), VvNRT1.1 (Vitis vinifera XP_002266951). C. Phylogeny of plant NRT1 polypeptides. CmNRT1 is boxed.

\section{CmNRT1 is induced by $10 \mathrm{mM} \mathrm{NO}_{3}^{-}$}

Inducible expression of $C m N R T 1$ was examined in roots and shoots of plants exposed to $10 \mathrm{mM} \mathrm{NO}_{3}$. As shown in Figure 2, expression of CmNRT1 was detected in both roots and shoots. At time 0, when the plants were depleted for nitrate, there was a low level of the CmNRT1 mRNA (Figure 2). However, at $4 \mathrm{~h}$ after the addition of nitrate, CmNRT1 mRNA levels increased approximately 2- and 7-fold in roots and shoots compared to time $0 \mathrm{~h}$, respectively (Figure 2). The high expression in shoots was still present at $2 \mathrm{~h}$ after nitrate addition. CmNRT1 mRNA levels began to decline at $4 \mathrm{~h}$ in roots and $2 \mathrm{~h}$ in shoots. 

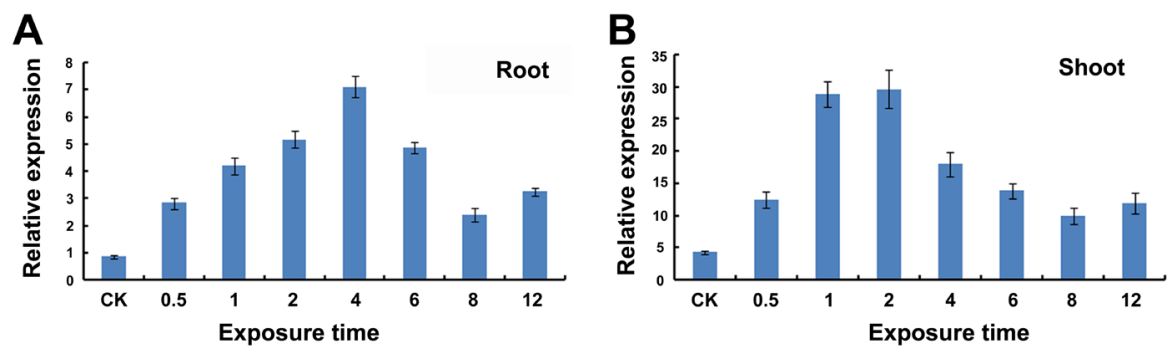

Figure 2. Induced transcription of CmNRT1 in roots and shoots exposed to $10 \mathrm{mM}$ nitrate following a period of $\mathrm{N}$ starvation. A. Roots. B. Shoots. Mean values and standard deviations calculated from triplicated assays.

\section{Root ${ }^{15} \mathrm{~N}$ influx in transgenic $A$. thaliana lines}

Overexpression of NRT1 in wild-type plants has been shown to be an effective approach for studying NRT1 function (Ma et al., 2011; Yang et al., 2012). To investigate the function of CmNRT1, we generated $A$. thaliana transgenic plants expressing CmNRT1. Based on PCR and RT-PCR assays (Figure $3 \mathrm{~A}$ and $\mathrm{B}$ ), two CmNRT1 transgenic plants were identified and designated as 35S:CmNRT1-1 and 35S:CmNRT1-2. The nitrate uptake of wild-type plants and the two CmNRT1 transgenic lines was compared after treatment with 0.2 or $10 \mathrm{mM}{ }^{15} \mathrm{NO}_{3}$ for $30 \mathrm{~min}$. We found that $C m N R T 1$ promoted ${ }^{15} \mathrm{NO}_{3}$ uptake at $10 \mathrm{mM}{ }^{15} \mathrm{NO}_{3}$ but not at $0.2 \mathrm{mM}{ }^{15} \mathrm{NO}_{3}$. This result suggested that $C m N R T 1$ encodes a constitutive component of a low-affinity transporter.

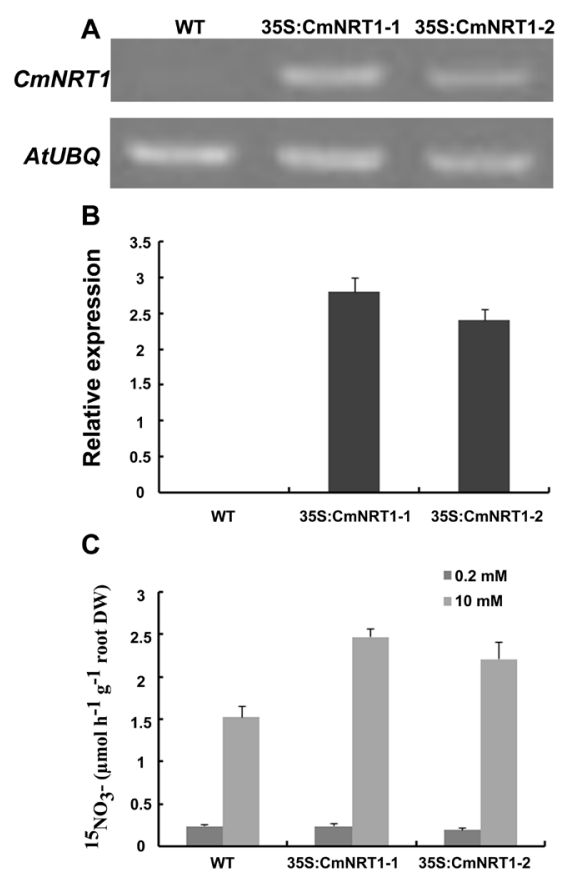

Figure 3. Influx of ${ }^{15} \mathrm{~N}$ into the roots of transgenic and non-transgenic Arabidopsis thaliana plants. A. B. C. Nitrate uptake of wild-type plants and transgenic $A$. thaliana using 10 or $0.2 \mathrm{mM}^{15} \mathrm{NO}_{3}$ for $30 \mathrm{~min}$. Values are reported as means \pm SE $(\mathrm{N}=3)$. 


\section{DISCUSSION}

Nitrogen is one of the most important mineral nutrients for plant development (Presterl et al., 2002). Under conditions of constant nitrogen levels, the relative ability of plants to acquire nitrogen is a crucial factor in achieving higher $\mathrm{N}$ efficiency (Moll et al., 1982). Here, we examined variation in nitrogen acquisition among sixteen chrysanthemum varieties. The relative nitrogen content of all genotypes was greater than 1, indicating that the nitrogen content under normal nitrogen levels (4 $\mathrm{mM})$ was higher than under low nitrogen levels $(0.2 \mathrm{mM})$ (Table 2$)$. The chrysanthemum variety 'Nannongxuefeng' showed the highest nitrogen acquisition of the tested varieties; therefore, it potentially carries excellent nitrogen-related genes. Here, we isolated the CmNRT1 homologue from this variety.

The sequence of CmNRT1 shows strong conservation with those of other NRT1 genes (Figure 2B). Genes in the NRT1 family can be divided into constitutive and nitrate-inducible types (Criscuolo et al., 2012). CmNRT1 is a nitrate-inducible gene like BnNRT1 and BcNRT1 (FaureRabasse et al., 2002; Yang et al., 2012). In contrast, rice OsNRT1 (Lin et al., 2000), tomato LeNRT1-1 (Lauter et al., 1996) and Arabidopsis AtNRT1:2 (Huang et al., 1999) are constitutive genes, which show relatively stable expression before and after nitrate induction. Similar levels of CmNRT1 expression were detected in roots and shoots. However, in other species, NRT1 genes show widely variable levels of expression in different tissues. For example, OsNRT1 is a rootspecific gene with little or no expression in the shoot (Lin et al., 2000), whereas OsNRT1.2 is only expressed in roots (Ma et al., 2011). In Arabidopsis, AtNRT1.8 is preferentially expressed in vascular tissues (Li et al., 2010), while AtNRT1.9 is predominantly expressed in roots (Wang and Tsay, 2011), and AtNRT1.11 and AtNRT1.12 are mainly expressed in larger expanded leaves (Hsu and Tsay, 2013).

CHL1 is a dual-affinity nitrate transporter in Arabidopsis and is involved in multiple phases of nitrate uptake (Liu et al., 1999; Ho et al., 2009). Phosphorylated and dephosphorylated CHL1 show low and high levels of response, respectively (Ho et al., 2009). However, the Arabidopsis homolog, AtNRT1:2, is a low-affinity nitrate transporter (Huang et al., 1999; Liu et al., 1999). CHL1 homologous proteins in other plants, such as LeNrt1.1 of tomato, OsNRT1 of rice and BcNRT1 of Chinese cabbage, are also low-affinity transporters (Lauter et al., 1996; Lin et al., 2000; Yang et al., 2012). Only low-affinity nitrate uptake activity was observed in OsNRT1-injected oocytes and BcNRT1 can restore ch/1-5 nitrate uptake at $10 \mathrm{mM}$ but not at $0.2 \mathrm{mM}$ nitrate (Lin et al., 2000; Yan et al., 2011). Nitrate uptake in A. thaliana heterologously expressing CmNRT1 (Figure 3) showed that CmNRT1 has a similar function to OsNRT1 and BcNRT1.

\section{Conflicts of interest}

The authors declare no conflict of interest.

\section{ACKNOWLEDGMENTS}

We thank Professor Guohua Xu and Dr. Xiaorong Fan (College of Resources and Environmental Sciences, Nanjing Agricultural University) for helping with the experiment on determination of nitrogen. Research supported by the National Natural Science Foundation of China (\#31425022, \#31272202), "948” Project of Ministry of Agriculture (\#2011-G17), the 
Fundamental Research Funds for the Central Universities (\#KYTZ201401), the Program for New Century Excellent Talents in University of Chinese Ministry of Education (\#NCET-12-0890), and the Program for Hi-Tech Research, Jiangsu, China (\#BE2012350).

\section{REFERENCES}

Almagro A, Lin SH and Tsay YF (2008). Characterization of the Arabidopsis nitrate transporter NRT1.6 reveals a role of nitrate in early embryo development. Plant Cell 20: 3289-3299. http://dx.doi.org/10.1105/tpc.107.056788

Barbosa JG, Kampf AN, Prieto MHE, Koller OC, et al. (2000). Chrysanthemum cultivation in expanded clay. I. Effect of the nitrogen-phosphorus-potassium ratio in the nutrient solution. J. Plant Nutr. 23: 1327-1336. http://dx.doi. org/10.1080/01904160009382103

Britto D and Kronzucker $\mathrm{H}$ (2004). Biotechnology of nitrogen acquisition in rice-implications for food security. In: Nitrogen Acquisition and Assimilation in Higher Plants (Amancio S and Stulen I, eds.). Kluwer Academic Publishers, The Netherlands, 261-281.

Chen S, Miao H, Chen F, Jiang B, et al. (2009). Analysis of expressed sequence tags (ESTs) collected from the inflorescence of chrysanthemum. Plant Mol. Biol. Rep. 27: 503-510. http://dx.doi.org/10.1007/s11105-009-0103-6

Covelo F, Rodriguez A and GallardoA (2008). Spatial pattern and scale of leaf $\mathrm{N}$ and P resorption efficiency and proficiency in a Quercusrobur population. Plant Soil 311: 109-119. http://dx.doi.org/10.1007/s11104-008-9662-9

Criscuolo G, Valkov VT, Parlati A, Alves LM, et al. (2012). Molecular characterization of the Lotus japonicus NRT1(PTR) and NRT2 families. Plant Cell Environ. 35: 1567-1581.http://dx.doi.org/10.1111/j.1365-3040.2012.02510.x

Fan SC, Lin CS, Hsu PK, Lin SH, et al. (2009). The Arabidopsis nitrate transporter NRT1.7, expressed in phloem, is responsible for source-to-sink remobilization of nitrate. Plant Cell 21: 2750-2761.http://dx.doi.org/10.1105/tpc. 109.067603

Faure-Rabasse S, Le Deunff E, Lainé P, Macduff JH, et al. (2002). Effects of nitrate pulses on BnNRT1 and BnNRT2 genes: mRNA levels and nitrate influx rates in relation to the duration of $\mathrm{N}$ deprivation in Brassica napus L. J. Exp. Bot. 53: 17111721.http://dx.doi.org/10.1093/jxb/erf023

Gu C, Chen S, Liu Z, Shan H, et al. (2011). Reference gene selection for quantitative real-time PCR in Chrysanthemum subjected to biotic and abiotic stress. Mol. Biotechnol. 49: 192-197.http://dx.doi.org/10.1007/s12033-011-9394-6

Gu CS, Liu LQ, Zhao YH, Deng YM, et al. (2014a). Overexpression of Iris. lactea var. chinensis metallothionein IIMT2a enhances cadmium tolerance in Arabidopsis thaliana. Ecotoxicol. Environ. Saf. 105: 22-28.http://dx.doi.org/10.1016/j. ecoenv.2014.04.002

Gu C, Zhang X, Jiang J, Guan Z, et al. (2014b). Chrysanthemum CmNAR2 interacts with CmNRT2 in the control of nitrate uptake. Sci. Rep.-UK 4: 5833

Guo R, Li X, Christie P, Chen Q, et al. (2008). Influence of root zone nitrogen management and a summer catch crop on cucumber yield and soil mineral nitrogen dynamics in intensive production systems. Plant Soil 313: 55-70. http://dx.doi. org/10.1007/s11104-008-9679-0

Ho CH, Lin SH, Hu HC and Tsay YF (2009). CHL1 functions as a nitrate sensor in plants. Cell 138: 1184-1194.http://dx.doi. org/10.1016/j.cell.2009.07.004

Hsu PK and Tsay YF (2013). Two phloem nitrate transporters, NRT1.11 and NRT1.12, are important for redistributing xylemborne nitrate to enhance plant growth. Plant Physiol. 163: 844-856.http://dx.doi.org/10.1104/pp.113.226563

Huang CB, Fang WM, Yang Y, Chen F, et al. (2010). Effects of different nitrogen levels and forms on the appearance quality and photosynthesis characters of potted chrysanthemum with small inflorescences. Acta Agr. Zhejiangensis 1: 45-50.

Huang NC, Liu KH, Lo HJ and Tsay YF (1999). Cloning and functional characterization of an Arabidopsis nitrate transporter gene that encodes a constitutive component of low-affinity uptake. Plant Cell 11: 1381-1392.http://dx.doi.org/10.1105/ tpc.11.8.1381

Jiang BB, Fang WM, Chen FD andGu JJ (2008). Effects of N, P and K ratio on the growth and development of cut chrysanthemum 'Jinba'. J. Zhejiang Forestry College 6: 692-697.

Kotur Z, Mackenzie N, Ramesh S, Tyerman SD, et al. (2012). Nitrate transport capacity of the Arabidopsis thaliana NRT2 family members and their interactions with AtNAR2.1. New Phytol. 194: 724-731.http://dx.doi.org/10.1111/j.1469$\underline{8137.2012 .04094 . x}$

Koutroubas S and Ntanos D (2003). Genotypic differences for grain yield and nitrogen utilization in Indica and Japonica rice under Mediterranean conditions. Field Crops Res. 83: 251-260. http://dx.doi.org/10.1016/S0378-4290(03)00067-4

Lauter F-R, Ninnemann O, Bucher M, Riesmeier JW, et al. (1996). Preferential expression of an ammonium transporter and of two putative nitrate transporters in root hairs of tomato. Proc. Natl. Acad. Sci. USA 93: 8139-8144.http://dx.doi. org/10.1073/pnas.93.15.8139 
Li JY, Fu YL, Pike SM, Bao J, et al. (2010). The Arabidopsis nitrate transporter NRT1.8 functions in nitrate removal from the xylem sap and mediates cadmium tolerance. Plant Cell 22: 1633-1646.http://dx.doi.org/10.1105/tpc.110.075242

Li XN, Sheng JD, Hou J and Xing X (2007). Screening for nitrogen efficiency in different cotton varieties at seeding stage. J. Xinjiang Agr. Univ. 3: 010.

Liao JP, Lin XG, Cao ZH, Shi YQ, et al. (2003). Interactions between arbuscular mycorrhizae and heavy metals under sand culture experiment. Chemosphere 50: 847-853.http://dx.doi.org/10.1016/S0045-6535(02)00229-1

Lin CM, Koh S, Stacey G, Yu SM, et al. (2000). Cloning and functional characterization of a constitutively expressed nitrate transporter gene, OsNRT1, from rice. Plant Physiol. 122: 379-388.http://dx.doi.org/10.1104/pp.122.2.379

Lin SH, Kuo HF, Canivenc G, Lin CS, et al. (2008). Mutation of the Arabidopsis NRT1.5 nitrate transporter causes defective root-to-shoot nitrate transport. Plant Cell 20: 2514-2528.http://dx.doi.org/10.1105/tpc.108.060244

Liu KH, Huang CY and Tsay YF (1999). CHL1 is a dual-affinity nitrate transporter of Arabidopsis involved in multiple phases of nitrate uptake. Plant Cell 11: 865-874.http://dx.doi.org/10.1105/tpc.11.5.865

Liu Z, Gu C, Chen F, Yang D, et al. (2012). Heterologous expression of a Nelumbo nucifera phytochelatin synthase gene enhances cadmium tolerance in Arabidopsis thaliana. Appl. Biochem. Biotechnol. 166: 722-734.http://dx.doi.org/10.1007/ s12010-011-9461-2

Livak KJ and Schmittgen TD (2001). Analysis of relative gene expression data using real-time quantitative PCR and the $2^{(-\Delta \Delta}$ ${ }^{C(T)) ~ M e t h o d . ~ M e t h o d s ~ 25: ~ 402-408 . h t t p: / / d x . d o i . o r g / 10.1006 / m e t h .2001 .1262 ~}$

Ma C, Fan XR and Xu GH (2011). Responses of rice plants of Wuyunjing 7 to nitrate as affected by over-expression of OsNRT1.2. Chin. J. Rice Sci. 4: 349-356.

Moll R, Kamprath E and Jackson W (1982). Analysis and interpretation of factors which contribute to efficiency of nitrogen utilization. Agron. J. 74: 562-564. http://dx.doi.org/10.2134/agronj1982.00021962007400030037x

Presterl T, Groh S, Landbeck M, Seitz G, et al. (2002). Nitrogen uptake and utilization efficiency of European maize hybrids developed under conditions of low and high nitrogen input. Plant Breed. 121: 480-486. http://dx.doi.org/10.1046/j.1439$\underline{0523.2002 .00770 . x}$

Remans T, Nacry P, Pervent M, Girin T, et al. (2006). A central role for the nitrate transporter NRT2.1 in the integrated morphological and physiological responses of the root system to nitrogen limitation in Arabidopsis. Plant Physiol. 140: 909-921.http://dx.doi.org/10.1104/pp.105.075721

Shi WM, Xu WF, Li SM, Zhao XQ, et al. (2010). Responses of two rice cultivars differing in seedling-stage nitrogen use efficiency to growth under low-nitrogen conditions. Plant Soil 326: 291-302. http://dx.doi.org/10.1007/s11104-009-0007-0

Tsay YF, Schroeder JI, Feldmann KA and Crawford NM (1993). The herbicide sensitivity gene CHL1 of Arabidopsis encodes a nitrate-inducible nitrate transporter. Cell 72: 705-713.http://dx.doi.org/10.1016/0092-8674(93)90399-B

Wang YY and Tsay YF (2011). Arabidopsis nitrate transporter NRT1.9 is important in phloem nitrate transport. Plant Cell 23: 1945-1957.http://dx.doi.org/10.1105/tpc.111.083618

Yan M, Fan X, Feng H, Miller AJ, et al. (2011). Rice OsNAR2.1 interacts with OsNRT2.1, OsNRT2.2 and OsNRT2.3a nitrate transporters to provide uptake over high and low concentration ranges. Plant Cell Environ. 34: 1360-1372.http://dx.doi. org/10.1111/j.1365-3040.2011.02335.x

Yang X, Sun F, Xiong A, Wang F, et al. (2012). BcNRT1, a plasma membrane-localized nitrate transporter from non-heading Chinese cabbage. Mol. Biol. Rep. 39: 7997-8006.http://dx.doi.org/10.1007/s11033-012-1646-4

Zhang L, Spiertz JHJ, Zhang S, Li B, et al. (2008). Nitrogen economy in relay intercropping systems of wheat and cotton. Plant Soil 303: 55-68. http://dx.doi.org/10.1007/s11104-007-9442-y

Zhou JJ, Theodoulou FL, Muldin I, Ingemarsson B, et al. (1998). Cloning and functional characterization of a Brassica napus transporter that is able to transport nitrate and histidine. J. Biol. Chem. 273: 12017-12023.http://dx.doi.org/10.1074/ jbc.273.20.12017 